\title{
Depoimento sobre a Reunião Preparatória da Oea para a Convençāo Interamericana de Direito Internacional Privado Sobre a Proteção dos Consumidores (Cidip VII)
}

\section{Madelaine Mooney \\ Pace University - UFRGS}

The CIDIP VII was an amazing opportunity. Never would I have imagined that I would have had an experience such as this while in Brazil. Although I have little to no experience in the area of law, especially intemational consumer law, this weekend-long conference was an amazing leaming experience in the area of international relations and in creating an international standard of consumer protection.

Among other things, it was an amazing honor to meet so many highly respected people in the area of international consumer law, and to be able to discuss with them and learn from them. Many interesting discussions were had. It was also wonderful to meet the Americans who came into town for the event, and learn where my home country stands on the issue, and how USA-Latin American relations arc developing and progressing.

I am very curious to see how the discussions play out in creating a more comprehensive set of international consumer laws. Again, this was a wonderful opportunity, and I am very grateful to have had this experience because back home, these types of conferences are very rarely open to students other than those studying law or international relations. For a sociology student this is a very interesting event to have participated in. So, again, thank you to Profa. Claudia for giving me this opportmnity. 
